\title{
Kültürel Miras Turizminde Bireysel Seyahat Maliyet Yönteminin Uygulanması*
}

Application of Individual Travel Cost Method in Cultural Heritage Tourism

\author{
Gülsüm SADIK**, Seda SÜER*** \\ ** Yüksek Lisans Öğrencisi, İzmir Kâtip Çelebi Üniversitesi Sosyal Bilimler Enstitüsü Turizm İşletmeciliği, Balatçık Kampüsü, PK 35620, Çiğli, İzmir. \\ E-posta: gulsumsadik@hotmail.com \\ ORCID: 0000-0001-6082-3285 \\ *** (Sorumlu Yazar), Dr. Öğr. Üyesi, İzmir Kâtip Çelebi Üniversitesi Turizm Fakültesi, Çiğli Ana Yerleşke Merkezi, No: 33/2, PK 35620, Çiğli, İzmir. \\ E-posta: seda.suer@ikcu.edu.tr \\ ORCID: 0000-0002-0264-071X
}

\section{MAKALE BILGILERI}

Makale işlem bilgileri:

Gönderilme tarihi: 23 Mayıs 2020

Düzeltme: 14 A ğustos 2020

Kabul: 10 Eylül 2020

Anahtar sözcükler: Kültürel miras turizmi, Ekonomik değerleme, Bireysel Seyahat Maliyet Yöntemi, Bergama Antik Kenti.

\section{ARTICLE INFO}

Article history:

Submitted: 23 May 2020

Resubmitted: 14 August 2020

Accepted: 10 September 2020

Key words: Cultural heritage tourism, Economic valuation, Individual travel cost method, Pergamon Ancient City.

\section{ÖZ}

Çalışmada, kültürel miras turizminin önemli merkezlerinden biri olan Bergama Antik Kenti'nin ekonomik değerinin belirlenmesi amaçlanmıştır. Bu amaçla, piyasa dıșı değerleme yöntemlerinden biri olan Bireysel Seyahat Maliyet Yöntemi (BSMY) uygulanmıştır. Bergama Antik Kenti'ni 2019 yılının Ağustos ayında ziyaret eden 400 kişiye yüz yüze anket tekniği uygulanmıştır. Çalışmada, Bergama Antik Kenti'nin bireysel seyahat maliyeti değerini ölçmek için çoklu doğrusal regresyon modeli kurularak analizi gerçekleștirilmiștir. Analizde bağımlı değișken olarak ziyaret sayısı kullanılmıștır. Bağımsız değișken olarak ise seyahat maliyeti, konaklama süresi, otopark masrafı, toplam ziyaret sayısı, ziyaretçi sayısı, yıllık kültür gezisi süresi ve ziyarete ayrılan süre olmak üzere toplam yedi bağımsız değişken kullanılmıştır. Çoklu doğrusal regresyon modeli analizi sonucu elde edilen bulgularla yıllık bireysel tüketici rantı ve toplam tüketici rantı hesaplanmıștır. Bulgulara göre, Bergama Antik Kenti'nin yıllık bireysel tüketici rantı 26.309 TL, toplam tüketici rantı ise 10.349.329.184 TL/yıl olarak bulunmuştur. Toplam Tüketici Rantı değeri, Bergama Antik Kenti'nin bir yıllık kültürel turizm kullanım değerine karşllık gelmektedir.

\section{Giriş}

Kültürel miras turizmi, insanların bir bölgenin somut veya somut olmayan kültür varlıklarını, gelenek ve göreneklerini tanımak, kültürel dene-

\footnotetext{
* Bu çalışma, İzmir Kâtip Çelebi Üniversitesi, Sosyal Bilimler Enstitüsü, Turizm İşletmeciliği Anabilim Dalı'nda, Dr. Öğr. Üyesi Seda Süer danışmanlığında yazılan, "Kültürel Mirasın Turizm Açısından Ekonomik Değerinin Belirlenmesi: Bergama Çok Katmanlı Peyzaj Alam Çalışması" başlıklı yüksek lisans tezinden üretilmiştir.
}

yimlerini geliştirmek amacıyla gerçekleştirdikleri seyahatlerdir. Kültürel miras alanlarına yapılan turistik faaliyetler ise kültürel miras turizmi kapsamındadır. Kültürel miras alanları arkeolojik, tarihsel kültür varlıkları, müzeler, ören yerleri, anitsal yapılar, dinsel yapılar, kırsal ve kentsel sivil mimari örnekleri, saraylar, kaleler, bahçeler, temalı parklar, mezarlar ve türbeler gibi her türlü doğal kültür ürünlerini içermektedir. Kültürel miras alanlarının turizm amacıyla kullanılmasıy- 
la kültürel miras alanının ekonomik boyutu ortaya çıkmaktadır. Ancak kültürel miras alanları, ürün olarak bir piyasa ürünü özelliği taşımayan yani herhangi bir üretim sonucu gerçekleşmemiş ve herhangi bir piyasası olmayan mallardır. Piyasa dişı mallar, hiçbir emek veya çaba harcanmadan, doğada hazır halde bulunan serbest mal özelliğini taşıyan mallardır. Ancak, piyasa dışı olan kültürel miras alanlarının günümüzde kültürel miras turizmi kapsamında kullanılmasıyla ekonomik değerinin belirlenmesi ihtiyacını doğurmaktadır.

Piyasa dışı malların ekonomik değerinin belirlenmesine yönelik ilk çalışma Harold Hotelling tarafından 1947'de ABD milli parklarının rekreasyon değerini tespit etmek amacıyla geliştirilmiştir (Hotelling 1949). Ekonomik değer, bir tüketicinin bir mal veya hizmet için ödemek istediği en yüksek değerdir ve bir mal veya hizmetin tüketiciye sağladığı fayda ile ölçülür. Kültürel miras alanının ekonomik değeri ise ziyaretçinin kültürel miras alanından faydalanmak için ödemek istediği en yüksek değerdir. Seyahat Maliyet Yöntemi (SMY), piyasa dışı değerleme, yani kültürel miras alanları ve kültürel mirasın korunması gibi düzenli piyasalarda alınıp satılmayan mallara parasal bir değer koymak için geliştirilen yaklaşımlardan biridir (Alberini ve Longo 2006: 288). SMY'nin temel varsayımı, ziyaretçilerin turistik bir alanı ziyaret etmek için yaptıkları toplam harcamalar ile harcadıkları zamanın, turistik alana ulaşmanın fiyatını temsil etmesidir. Yöntem ile farklı seyahat maliyetine sahip ziyaretçilerin turistik alana yaptıkları ziyaret sayısı veri alınarak, ziyaretçilerin alanı ziyaret etmek için ödemeye istekli oldukları değer tahmin edilmektedir (Alora ve Nandagiri 2015: 1316).

Ekonomik değerleme çalışmalarının temaları incelendiğinde milli parklar, tabiat parkları, kaplıcalar, göller, botanik bahçeleri, yağmur ormanları, akarsu raftingi ve plajlar üzerinde durulduğu tespit edilmiştir. Bu çalışmanın teması ise Bergama Antik Kenti'nde bulunan kültürel miras çekiciliklerinin turizm amacıyla kullanımının ekonomik değerini tespit etmektir. Türkiye'de kültürel miras alanlarının ekonomik değerinin belirlenmesine yönelik daha önce bir çalışma bu- lunmadığ 1 için bu çalışmanın alanyazına katkı sağlaması amaçlanmıştır. Bu çalışmada tema olarak Bergama Antik Kenti'nin seçilmesinin nedeni ise kentin 2014 yılında önemli bir tarih, kültür ve turizm kenti olarak 999. UNESCO Dünya Mirası olarak kabul edilmesidir. Bergama 8.500 yıllık tarihi geçmişe sahip, birçok uygarlığa ev sahipliği yapmış, dünyanın en eski yerleşimlerinden biridir. Bergama tarihsel süreç içerisinde "İlkler Kenti" olarak nitelendirilmiştir. Dünyanın en dik tiyatrosu olan Akropol'e, dünyanın ilk ruhsal tedavi merkezlerinden olan Asklepion'a, adı İncil'de de geçen Hristiyanlığın ilk yedi kilisesinden biri olan St. Jean Kilisesi'ne, dönemin sayılı ılıca yapılarından Allianoi'ye, ayrıca Osmanlı Dönemine ait konaklara, hanlara, hamamlara, camilere, çeşmelere vb. pek çok kültürel ve tarihi değere sahiptir (Gülhan 2016: 169). Bu çalışmada, eski medeniyetlerden günümüze varlığını sürdüren ancak herhangi bir piyasası olmayan kültürel miras alanının ekonomik değerini belirleme amacıyla daha önce geliştirilen çeşitli modellerden faydalanılmaktadır (Clawson ve Knetsch 1966).

\section{KURAMSAL ÇERÇEVE}

\section{Seyahat Maliyeti Yöntemi}

Seyahat Maliyeti Yöntemi (SMY), piyasa dışı malların turizm talebini tahmin etmek için kullanılan en yaygin yöntemdir. SMY ilk olarak, Harold Hotelling tarafından 1947'de ABD milli parklarının rekreasyon değerini tespit etmek amacıyla geliştirilmiştir (Hotelling 1949). Clawson ve Knetsch (1966) deneysel modeller geliştirerek, SMY'ni anketler ile elde edilen verilerin istatistiksel analizlerini yaparak uygulamıştır. Bu anketlerle ziyaret sayısı ile ziyaretçilerin ikametgâh bilgileri, seyahat amacı, seyahat süresi, seyahat mesafesi, seyahat maliyetleri gibi seyahate ilişkin bilgiler elde edilmektedir. Bunun sonucunda ziyaret sayısı ile seyahat maliyetleri ve diğer ilgili faktörlerle ilişkilendirilerek bir talep ilişkisi kurulabilmektedir (Das 2013:1).

Temel arz ve talep teorisi, genellikle bir malın fiyatı yükseldikçe daha az talep edildiğini göstermektedir. Bu teoriye göre, normal olarak seyahat maliyetlerinin büyüklügüune göre ziyaretlerin sayısı ters orantılıdır. Talep eğrisinin altında kalan 
alan tüketici rantını yani toplam faydayı temsil etmektedir (Bann 1998: 76). SMY, bireylerin ziyaret etmek için katlandıkları maliyet (ulaşım, konaklama ve parka giriş maliyetleri dahil) ve zamanlarının maliyetini inceleyerek bir alanı ziyaret etmeye verdikleri değeri ifade etmektedir. $\mathrm{Bu}$ veriler, bireylerin ziyaretten elde ettikleri tüketici fazlasını tahmin etmek için kullanılmaktadır (Baker ve Ruting 2014: 27). Pek çok rekreasyon, kültür, tarihi veya manzara alanlarının ekonomik değerini tespit etmede kullanılan SMY'nin ilkesi, bireylerin bu alanların girişinde ödedikleri giriş ücreti haricinde seyahat masrafı veya süresi gibi değişkenleri dikkate almaktadır (Bann 1998: 76).

SMY, başta Avustralya ve ABD olmak üzere gelişmiş batılı ülkelerde çok geniş bir uygulama alanı bulmuştur. Yöntem, doğal kaynaklardaki hasarların tanımlanması, doğal yaşam değerinin saptanması, rekreasyon alanların değerinin saptanması, temiz hava ve su değerinin saptanması, doğal felaketlerin hasarlarının saptanmaS1, hidroelektrik santralleri yenileme maliyetinin saptanması, havza yönetimi, su arzı politikaları, enerji sektörüne ilişkin politikaların oluşturulması ve orman alanlarının değerinin saptanması gibi durumlarda yaygın bir şekilde kullanılmaktadır (Dönmez 2013: 31). SMY, Bireysel Seyahat Maliyeti Yöntemi ve Bölgesel Seyahat Maliyeti Yöntemi olmak üzere iki farklı şekilde uygulanmaktadır. Bireysel Seyahat Maliyeti Yöntemi'nde bağımlı değişken, ziyaret alanının bireysel ziyaretçiler tarafından yıllık (veya sezon başına) ziyaret sayısıdır. Bölgesel Seyahat Maliyeti Yöntemi'nde ise bağımlı değişken, belirli bir bölge veya bölgenin nüfusu tarafından gerçekleştirilen ziyaret oranıdır (Fleming ve Cook 2008: 1198).

\section{Bireysel Seyahat Maliyet Yöntemi ile Yapılan Çalışmalar}

Yerli ve yabancı alanyazın incelendiğinde BSMY uygulanarak yapılan çeşitli çalışmalar bulunmaktadır. Menkhaus ve Lober (1996) Monteverde Bulut Ormanı'na Amerika'dan gelen turistlerin Kosta Rika yağmur ormanlarına eko-turizm açısından verdikleri değeri belirlemeyi amaçlamışlardır. Amerikalı 240 turistin katıldığı çalış- mada çoklu doğrusal regresyon analizi kullanılarak, yıllık eko-turizm değeri 4,5 milyon ABD Doları olarak bulunmuştur. Bowker, English ve Donovan (1996), çalışmalarında Georgia ve Güney Carolina arasındaki kuzey sınırının bir bölümünü oluşturan Chatooga Nehri ve kırsal batı Kuzey Carolina'daki Nantahala Nehri üzerindeki akarsu raftingi için seyahat başına tüketici fazlasını incelemişlerdir. Çalışmada poisson regresyon ve negatif binom modelleri kullanılmış ve ortalama tüketici rantının 89 ABD Doları ile 286 ABD Doları arasında olduğu bulunmuştur.

Ortaçeşme, Özkan ve Karagüzel (2002), çalışmalarında Antalya'da yer alan Kurşunlu Şelalesi Tabiat Parkı'nın rekreasyonel kullanım değerini belirlemeyi amaçlamışlardır. Bu çalışmada, Eylül 1998-Haziran 1999 tarihleri arasında parkı ziyaret edenlerle yüz yüze görüşme yoluyla gerçekleştirdikleri 500 anketten 280 anket analize dahil edilmiştir. Çalışmada yarı logaritmik fonksiyon kullanılmıştır. Çalışmanın bulgularına göre 1999 fiyatlarıyla, Kurşunlu Şelalesi Tabiat Parkı'nın yılda yaklaşık 21.500 milyon TL'lik rekreasyonel kullanımdan doğan bir ekonomik değere sahip olduğu belirlenmiştir.

Alberini ve Longo (2006) yaptıkları çalışmada Ermenistan'ın dört kültürel miras alanı (Garni, Haghardzin, Khor Virap ve Tatev) için ekonomik değerlerini tahmin etmeyi amaçlamışlardır. Bu amaçla, 7-25 Ağustos 2004 tarihleri arasında 500 ziyaretçiye yüz yüze anket tekniğini uygulamışlardır. Poisson regresyon modelinin kullanıldığ 1 çalışmanın sonuçlarına göre alanların kullanım değeri Garni'de 21.000 AMD (Ermenistan Dram1), Haghardzin ve Khor Virap'ta 19.000 AMD ve Tatev'de 13.850 AMD, kişi başı tüketici rantı ise ortalama 3.400 AMD olarak bulunmuştur.

Dilek Yarımadası Büyük Menderes Deltası Milli Parkı'nın rekreasyon amaciyla kullanımının ekonomik değerinin belirlenmesi için yapılan başka bir çalışmada 2006 yılı Eylül-Ekim aylarında 104 ziyaretçiye anket uygulanmıştır. Çalışmanın bulgularına göre, bir kişi için gezi başına tüketici rant1, 83,98 YTL olarak tespit edilmiştir. Milli Park'ın rekreasyonel kullanım değeri 41.990.000 YTL olarak belirlenmiştir (Başar 2007). Başar (2007) tüketici rantını hesaplamak için po- 
isson regresyon modelini kullanırken, Belkayalı (2009) Yalova Termal Kaplıcaları'nın ekonomik değerini belirlemek için yaptığı çalışmada basit doğrusal regresyon modelini kullanmıştır. Çalişmada, 17-20 Temmuz 2008 tarihlerinde toplam 154 ziyaretçiye anket uygulanmış, bireysel tüketici rant1 $3.120 \mathrm{TL}$, toplam tüketici rantı ise 1.239.014.400 TL/yıl olarak bulunmuştur. Demir (2013) ise Royal Botanik Bahçesi'nin rekreasyonel amaçlı kullanım değerini belirlediği çalışmasında, bireysel tüketici rantını kişi başı $165 £$, toplam tüketici rantını ise yıllık $268.950 .000 £$ olarak bulmuştur. Tüketici rantını hesaplamak için çoklu doğrusal regresyon modelini kullanmıştır. Çalışmanın verileri, 460 ziyaretçiye uygulanan anketten elde edilmiştir.

Bireysel seyahat maliyetinin uygulandığı diğer bir çalışmada, Uzungöl Doğa Parkı'nın rekreasyonel ve turizm amaçlı kullanımının ekonomik değeri belirlenmiştir. Çalışmanın verileri, Uzungöl Doğa Parkı'nı ziyaret eden 117 kişiye yüz yüze anket tekniği uygulanarak elde edilmiştir. Çalışmanın bulgularına göre, bir kişi için gezi başına tüketici rantı 333,33 TL olarak bulunmuştur. Kişi başına yıllık tüketici rantı 506.66 TL olup Uzungöl Doğa Parkı'nın rekreasyonel ve turizm amaçlı kullanım bedeli 101.332.000 TL/ yıl olarak hesaplanmıştır. Bu çalışmada tüketici rantının hesaplanması için poisson regresyon modeli kullanılırken (Dönmez 2013), Keenjhar Gölü'nün rekreasyonel değerini belirlemek için yapılan çalışmada negatif binom modeli kullanılmıştır. Gölü ziyarete gelen 500 kişiye yüz yüze anket tekniği uygulanmış ve veriler 422 anketten elde edilmiştir. Çalışmanın bulgularına göre, her ziyaretçi tarafından ödenen ortalama giriş ücreti 0,30 ABD Doları iken, bu çalışmada tahmini tüketici rantı, kişi başına 14 ABD Dolarıdır (Mangan vd. 2013). Zhang, Wang, Nunes ve Ma (2015) Gold Coast plajlarının rekreasyonel kullanım değerini belirledikleri çalışmada poisson regresyon modelini kullanmışlardır. Çalışmada 19-28 Kasım 2011 arasında, Paradise Beach, Narrowneck Beach, Main Beach ve Broad plajında 320 kişi ile anket yapılmıştır, ancak 291 anket çalışmaya dahil edilmiştir. Çalışmada tek bir plajın tüketici fazlası, yerel sakinleri için kişi başı 10.05 - 14.32 ABD Doları ve yılda yaklaşık 402 milyon ABD
Doları, diğer ziyaretçiler için kişi başı 16.67 ABD Doları -19.98 ABD Doları ve yıllık yaklaşık 117 milyon ABD Doları olarak bulunmuştur. Yılmaz (2016) Beydağları Sahil Milli Parkı'nın toplam ekonomik değerini belirlediği çalışmasında negatif binomial regreasyon modelini kullanmıştır. Çalışmada Nisan-Ağustos 2015 döneminde 194 kişiyle yüz yüze görüşülerek anket yapılmıştır. Çalışma sonucuna göre ziyaret başına bir kişi için elde edilen tüketici rant1 642,92 TL, y1llık rekreasyonel amaçlı kullanımı ekonomik değeri ise 1.398.351.000 TL olarak hesaplanmıştır. Apostolidis (2017), çalışmasında Yunanistan'ın Pella vilayetinde bulunan Pozar Kaplıcaları'nın işletilmesi ile ilgili termal turizme olan talebi analiz etmeyi amaçlamıştır. Ocak 2016 - Mart 2016 döneminde Pozar Kaplıcaları'na gelen 323 ziyaretçi ile yüz yüze anket çalışması yapılmıştır. Çalışmada poisson regresyon ve negatif binom modelleri kullanılmıştır. Çalışma sonucunda, tüketici fazlas1 poisson modeli ile $333.333 €$ ve negatif binom modeli ile $500 €$ olarak tahmin edilmiştir. Pozar Kaplıcaları'nın yıllık ekonomik değeri ise poisson modeli ile 85.650.666,67 $€$, negatif binom modeliyle $128.476 .000 €$ olarak tahmin edilmiştir. Ortega, Alvarez, Simal, Luis-Ruiz ve Garcia (2018) çalışmalarında UNESCO tarafından dünya mirası listesine alınan Altamira Mağarası'nın ekonomik değerini analiz etmeyi amaçlamışlardır. Çalışmada, 2013 yılında Ağustos 2013 ile Şubat 2014 arasında 1067 ziyaretçiye uyguladıkları anket verileri kullanılmıştır. Çalışmada poisson regresyon modeli kullanılarak bireysel tüketici rantı $31,95 €$ yıllık tüketici rantı ise 8,18 milyon $€$ bulunmuştur.

Başka bir çalışmada Alkan (2019), Troya Tarihi Milli Parkı'nın (TTMP) rekreasyon ve turizm amaçlı kullanımından kaynaklı ekonomik değeri tespit etmeyi amaçlamıştır. Bu amaçla ziyaretçilere tesadüfi olarak ve yüz yüze anket tekniği ile 450 anket uygulanmıştır. Çalışmada tüketici rantını hesaplamak için çoklu doğrusal regresyon modeli kullanılmıştır. TTMP için yıllık tüketici rantı değeri 192.075.466 TL olarak hesaplanmış, Kaz Dağları'nın turizm kaynaklarının ekonomik değerini belirlemek için yapılan başka bir çalışmada da bireysel tüketici rantı ve toplam tüketici rantı sirasiyla 3.959,46 TL ve 384.958.445,95 TL 
olarak bulunmuştur. Kaz Dağları'nda Ağustos Eylül 2016 ve Temmuz-Eylül 2017 dönemlerinde uygulanan anket çalışmasından 276 anket analizde kullanılmıştır (Özkök vd. 2019).

BSMY uygulanarak yapılan ekonomik değer belirlemeye yönelik yerli ve yabancı çalışmalar incelendiğinde bu çalışmaların milli parklar, tabiat parkları, kaplıcalar, göller, plajlar, botanik bahçeleri, yağmur ormanları, akarsu raftingi gibi konular üzerinde durulduğu tespit edilmiştir. Alanyazında, yabancı çalışmalarda kültürel miras alanlarının ekonomik değerinin belirlenmesi üzerine yapılmış çalışmalar (Alberini ve Longo 2006; Ortega vd. 2018) bulunurken, Türkiye'de bu konuda bir çalışmaya rastlanmamıştır. Alanyazın incelendiğinde BSMY uygulanarak yapılan çalışmalarda uygulanan modellerin çeşitlilik gösterdiği anlaşılmaktadır. Çalışmalarda çoklu doğrusal regresyon, yarı logaritmik regresyon, poission regresyon ve negatif binom regresyon gibi çeşitli modeller ve bu modellere ilişkin geliştirilen farklı tüketici rantı formülleri kullanılmıştır. Her regresyon modeline ait farklı tüketici rantı formülünden dolayı aynı çalışmanın verilerinin sonucunda bile farklı (yüksek veya düşük) tüketici rantlarının hesaplanmasına neden olmuştur.

\section{YÖNTEM}

\section{Bireysel Seyahat Maliyet Yöntemi}

BSMY rekreasyon alanını ziyaret eden ziyaretçilerin tüketici rantını belirlemek ve rekreasyon faaliyetlerinin ekonomik değerini belirlemek için uygulanmaktadır (Ortaçeşme vd. 2002: 58). BSMY'de bağımlı değişken, bir rekreasyon alanının bireysel kullanıcıları tarafından yıllık veya mevsim başına yapılan gezi sayısıdır (Fleming ve Cook 2008: 1198). BSMY'de genellikle kullanılan bağımlı ve bağımsız değişkenler aşağıdaki fonksiyonda gösterilmiştir (Willis ve Garrod 1991: 37):

$V_{i j}=f\left(C_{i j}, M_{i}, F_{i}, N_{i}, P_{i j}, E_{i j}, L_{i j}, A_{i}, Y_{i}, e_{i j}\right)$

Burada;

$\mathrm{V}_{\mathrm{ij}}$ : i bireyinin $\mathrm{j}$ alanına yılda yaptığg ziyaret sayisini,
$C_{i j:}$ i bireyinin $j$ alanına ulaşmak için yaptığı seyahat maliyetini,

$\mathrm{M}_{\mathrm{i}:}$ i bireyinin çevresel bir organizasyonun üyesi olup olmadığını (0 ve 1 kukla değişken),

Fi: i bireyi tarafından alternatif alanların olup olmadığını (0 ve 1 kukla değişken),

$\mathrm{N}_{\mathrm{i}}$ : i bireyine eşlik eden grubun büyüklüğünü,

$P_{\mathrm{ij}}$ : i bireyinin seyahatinde $\mathrm{j}$ alanına ziyaretinin tek amacı olup olmadığını (0 ve 1 kukla değişken),

Eij: i bireyinin $\mathrm{j}$ alanına yaptığı ziyaretten memnun kalma oranin,,

Lij: i bireyinin j alanında harcadığ $\breve{1}$ zamanı,

Ai: i bireyinin yaşını,

$Y_{i:}$ i bireyinin gelir endeksini,

$e_{i j:}$ hata terimini ifade eder.

BSMY uygulamalarında araştırmacılar, inceledikleri alana uygun olarak farklı bağımsız değişkenler kullanabilmektedir.

\section{Toplam Seyahat Maliyeti Değerinin Hesaplanması}

Çalışmalarda BSMY'nin uygulanabilmesi için öncelikle toplam seyahat maliyeti değerinin hesaplanması gerekmektedir. SMY'nin uygulandığı çalışmalar incelendiğinde, toplam seyahat maliyeti değerinin tespit edilmesinde birbirinden farklı yaklaşımların uygulandığı görülmektedir. Başar (2007), çalışmasında toplam seyahat maliyeti değerini; ulaşım masrafı, giriş ücreti, parkta tüketmek amacıyla ve park içinde yapılan harcamalar ve varsa parka gelmek için vazgeçilen kazancın toplamı olarak hesaplamıştır. Yılmaz (2016), çalışmasında seyahat maliyeti değerini; "yakıt", "toplu ulaşım", "park dışında yaptığınız harcamalar (yakıt hariç)" ve "park içinde yaptığınız harcamalar" olmak üzere dört gruba ait sorulara verilen yanıtların toplamıyla elde etmiştir.

Seyahat ve turistik alanda harcanan zamanin fırsat maliyetinin hesaplanmasında çok farklı yaklaşımlar bulunmaktadır. BSMY çalışmalarında, başlangıçta seyahat maliyeti değeri hesaplamalarında sadece ulaşım harcamaları bulunurken, zamanla turistik alana giriş ücretleri, seyahat süresinin ve turistik alanda geçirilen zamanın maliyeti ve diğer harcamalar da etkili olmuştur. 
Seyahat maliyetini etkileyen harcama kalemlerinin neler olduğu, araştırmacının amacına ve araştırma olanaklarına bağlı olarak değişmektedir (Mathis vd. 2004'ten aktaran: Demircioğlu 2014: 68). Bu çalışmada, seyahat maliyet değerini elde etmek için öncelikle toplam seyahat harcamaları hesaplanmıştır. Toplam seyahat harcamaları, Tablo 1'de verilen gider türlerinin toplamından oluşmaktadır.

Pak'a (2003) göre toplam seyahat maliyetinin diğer bir bileşeni de turistik alana ulaşmak için harcanan zamanın ve turistik alanda harcanan zamanın firsat maliyetidir. Zamanın firsat maliyetinin hesaplanmasında kullanılan en yaygın yöntem, turistik alanı ziyaret eden kişinin gelirinin belirli bir yüzdesinin bir zaman dilimi için fırsat maliyeti olarak kabul edilmesidir (Ortaçeşme vd. 1999: 110). Willis ve Garrod (1991), zamanın firsat maliyetini belirlemede İngiltere Ulaştırma Bakanlığg'nın resmi olarak kullandığı bir değer olan ziyaretçilerin gelirlerinin yüzde 43'ünü hesaplamışlar ve bu değeri seyahat süresinin maliyeti olarak kabul etmişlerdir. Bu çalışmada seyahat maliyeti değeri, ziyaretçilerin aylık gelirlerinin yüzde 43'ü fırsat maliyeti olarak hesaplanmış ve toplam seyahat harcamalarına eklenerek elde edilmiştir. Çalışmada BSMY ile

Tablo 1. Toplam Seyahat Maliyeti Değerini Oluşturan Harcama Türleri

\begin{tabular}{lr}
\hline Harcama Türleri & Harcama Tutarı \\
\hline Ulaşım Masrafları & $67.916 \mathrm{TL}$ \\
\hline Konaklama Masrafları & $31.871 \mathrm{TL}$ \\
\hline Yiyecek-İçecek Masrafları & $43.038 \mathrm{TL}$ \\
\hline Giriş Ücreti & $30.753 \mathrm{TL}$ \\
\hline Hediyelik Eşya Harcamaları & $11.636 \mathrm{TL}$ \\
\hline Otopark Ücreti & $1.838 \mathrm{TL}$ \\
\hline Diğer Harcamalar & $2.040 \mathrm{TL}$ \\
\hline Toplam Harcamalar & $189.092 \mathrm{TL}$ \\
\hline
\end{tabular}

ekonomik değeri belirlemek için, Bergama Antik Kenti'ni 2019 Ağustos ayında ziyaret eden 400 kişiye yüz yüze anket tekniği uygulanmıştır. Anket çalışması İzmir Kâtip Çelebi Üniversitesi Sosyal Araştırmalar Etik Kurulu'nun 08.08.2019 tarihli ve 2019/06-04 sayılı kararı ile onaylanmıştır. Anket yoluyla elde edilen veriler, SPSS 25.0 programı kullanılarak analiz edilmiştir. Tablo 2'de toplam seyahat maliyeti değerine ilişkin tanımlayıcı istatistikler verilmektedir.

\section{Bireysel Seyahat Maliyeti Modeli ve Tüketici Rantı}

Çalışmada bireysel seyahat modelini oluşturabilmek için çoklu doğrusal regresyon modeli kullanılmıştır. Çoklu doğrusal regresyon modelinde $\mathrm{H}_{0}$ hipotezi tüm regresyon katsayılarının sıfıra eşit olduğu $\left(\mathrm{H}_{0}: \beta_{1}=\beta_{2}=\ldots=\beta_{\mathrm{p}}=0\right)$ şeklinde kurulurken, $\mathrm{H}_{1}$ hipotezi en az bir $\beta_{i}{ }^{\prime}$ nin sifirdan farklı olduğu şeklinde kurulur (Kalaycı 2018: 259). Çoklu doğrusal regresyon modeli, bir bağımlı değişken ile bununla ilişkisi olan bir dizi bağımsız değişken arasındaki ilişkiyi ortaya koymak için yapılan bir analizdir (Can 2018: 273). Parametrelerin istatistiksel anlamlılığı için t-testi ve modelin bir bütün olarak anlamlı olup olmadığını test etmek için ise F testi uygulanmıştır. Çalışmanın asıl amacı, yıllık ziyaret sayısının (talebin) üzerinde etkisi olduğu düşünülen değişkenlerden her birinin ziyaret sayısını (talebi) hangi öncelikle ve ne derecede açıkladığını ortaya çıkarmaktır. Bu amaçla oluşturulan Bergama Antik Kenti Talep Modeli aşağıdaki gibidir:

$\mathrm{YZS}=\beta_{0}+\beta_{1} \mathrm{SM}_{\mathrm{i}}+\beta_{2} \mathrm{KS}_{\mathrm{i}}+\beta_{3} \mathrm{OM}_{\mathrm{i}}+\beta_{4} \mathrm{TZS}_{\mathrm{i}}+\beta_{5} \mathrm{ZKS}_{\mathrm{i}}$ $+\beta_{6} \mathrm{YKGS}_{\mathrm{i}}+\beta_{7} \mathrm{ZAS}_{\mathrm{i}}+\mathrm{eib}_{\mathrm{ib}}$

Bergama Antik Kenti'ne ait talep fonksiyonu ise aşağıda gösterilmiştir.

$Y Z S_{i}=f\left(S M_{i b}, K S_{i b}, O M_{i b}, T S_{i b}, Z K S_{i b}, Y K G S_{i}\right.$, $\left.Z A S_{i}\right)$

Tablo 2. Toplam Seyahat Maliyeti Değerine İlişkin Tanımlayıcı İstatistikler

\begin{tabular}{lrrrrr}
\hline & $N$ & En az & En çok & Ortalama & Medyan \\
\hline Toplam Seyahat & 400 & 10,00 & 7056,00 & 482,0575 & 673,44777 \\
\hline
\end{tabular}


Tablo 3. Model Özeti

\begin{tabular}{lccccr}
\hline Model & R & R Kare & Düzeltilmiş R Kare & Tahminin Std. Hatası & Durbin-Watson \\
\hline 1 &, 898 &, 807 &, 803 &, 98019 & 1,742 \\
\hline
\end{tabular}

Burada;

YZS ib: i bireyinin Bergama Antik Kenti'ne bir yıl içinde yaptığı ziyaret sayısını,

SMib: i bireyinin Bergama Antik Kenti'ne seyahati boyunca yaptı̆̆ 1 ziyaretin maliyetini,

$\mathrm{KS}_{\mathrm{ib}}$ : i bireyinin Bergama Antik Kenti'ne ziyareti için yaptığı konaklama süresini,

OMib: i bireyinin Bergama Antik Kenti ziyaretinde ödediği otopark masrafını,

TZSib: i bireyinin Bergama Antik Kenti'ne toplam ziyaret sayısını,

ZKS ib: i bireyinin Bergama Antik Kenti'ni kaç kişi ile ziyaret ettiğini,

YKGSi: i bireyinin kültür gezilerine yıllık ayırdığı süreyi,

ZAS ib: i bireyinin Bergama Antik Kenti'ne ayırd1ğ1 süreyi,

$\beta$ ib : parametrelerin katsayısını,

e ib : hata payını göstermektedir.

Model özeti tablosunda R kare, bağımlı değişkenin bağımsız değişkenler tarafından açıklanma yüzdesini ifade eder. Bu sonuçlara göre, bağımlı değişkenin yüzde 81'inin bağımsız değişkenler tarafından açıklandığı görülmektedir. Yine tabloda önemli bir test ise Durbin-Watson testidir. Bu test modelde otokorelasyonun tespiti için uygulanır. Genellikle 1,5 ile 2,5 arasında sonuç veren Durbin-Watson testi değeri modelde otokorelasyon olmadığını gösterir. Buna göre, modelde bulunan Durbin-Watson testi değeri $(1,742)$ modelde otokorelasyon olmadığını göstermektedir.
Tüketici rantının tespit edilmesi için yapılan regresyon analizi sonuçlarına göre modelin anlamlılığ 1 varyans analizi ile test edilmiştir. Buna göre, kurulan model her düzeyde anlamlı bulunmuştur. (Sig. =,000).

Modeldeki değişkenlerden elde edilen sonuçlar, bireysel seyahat maliyeti yöntemi uygulamalarındaki teorik beklentilerle uyumludur. Toplam seyahat maliyeti değişkeninin negatif (-) $\beta$ değeri alması, maliyet (fiyat) ile bir yılda yapılan ziyaret sayısı (talep) arasında ters ilişki olduğunu göstermektedir. Bir başka deyişle, toplam seyahat maliyeti (fiyat) arttıkça ziyaret sayısı (talep) azalmaktadır. İncelenen bağımsız değişkenlerden elde edilen sonuçlar istatistiksel anlamda önem düzeyleri bakımından değerlendirildiğinde, tüm bağımsız değişkenlerin 0,05 düzeyinde, önemli olduğu görülmektedir.

Bireysel seyahat maliyet yönteminde tüketici rantı değerine, yukarıda verilen bireysel seyahat maliyet modelinin belirli integrali alınarak ulaşılmaktadır. i bireyinin turistik alana ulaşımıyla ilgili hesaplanacak tüketici rantı değeri aşağıda verilen eşitlikle hesaplanmaktadır (Czajkowski vd. 2019: 966):

Tüketici Rantı=

$p_{i}{ }^{*}$

$\int_{p_{i}{ }^{0}} f\left(p_{i}, z_{i}\right) d p_{i}$

Burada;

$p_{i}$ : Gezi alanına ulaşmak için ziyaretçiler tarafından yapilan maliyeti,

Tablo 4. Varyans Analizi

\begin{tabular}{llrrrr}
\hline Model & $\begin{array}{c}\text { Kareler } \\
\text { Toplamı }\end{array}$ & $\begin{array}{c}\text { Serbestlik } \\
\text { Derecesi }\end{array}$ & $\begin{array}{r}\text { Ortalama } \\
\text { Kare }\end{array}$ & $\begin{array}{c}\text { Önem deği } \\
\text { Düzeyi }\end{array}$ \\
\hline 1 & Regresyon & 1572,874 & 6 & 224,696 & 233,870 \\
\hline Kalıntı & 376,623 & 392 & 961 & \\
\hline
\end{tabular}


Zi: Ziyaret sayısını etkilediği düşünülen ziyaretçinin bireysel özelliklerini,

$p_{i}^{0}$ : Seyahat maliyetini,

$p_{i}^{*}$ : Ziyaret sayısını sıfır (0) yapan seyahat düzeyini göstermektedir.

Bireysel tüketici rantı değeri, ziyaretçilerin turistik alana gerçekleştirdikleri yıllık ziyaret sayısi ile toplam seyahat maliyeti arasında yapılacak regresyon analizi sonucunda bulunacak ilişki katsayısı kullanarak hesaplanmaktadır. Doğrusal fonksiyon tipine göre hesaplanan tüketici rant1 formülü aşağıda verilmiştir (Adamowicz vd. 1989: 416):

$\mathrm{TR}=-\frac{q^{2}}{2 \beta}$

Burada;

TR: Bireysel tüketici rantını,

q: Bireylerin bir yılda yaptığ ziyaretlerin ortalamasinı,

$\beta$ : Talep fonksiyonunun eğimini (harcama katsayıs1) göstermektedir.

Formüldeki q değeri, ekonomik analize katılan 400 ziyaretçinin bir yılda Bergama Antik Kenti'ne yapmış oldukları ziyaretler toplamının ortalamasıdır. Bu değer 1,365'tir. Bu değer tüketici rantı formülünde yerine konulursa, bireysel tüketici rantı:

$$
\mathrm{TR}=-\frac{1,365^{2}}{2(-0.00003541)}
$$

$$
\mathrm{TR}=26.309 \mathrm{TL}
$$

olarak bulunmaktadır.

Hesaplanan bireysel tüketici rantı değerinin, Bergama Antik Kenti'ni bir yılda ziyaret edenlerin toplam sayısı ile çarpılması sonucu, toplam tüketici rantı değeri elde edilmiştir. Bergama Müzesi Müdürlüğü 2019 yılı verilerine göre Bergama Antik Kenti'ne bir yılda ziyaret edenlerin sayısı 393.376 kişidir. Buna göre toplam tüketici rant1:

Toplam Tüketici Rant1: 26.309 TL x $393.376=$ 10.349.329.184 olmaktadır.
BSMY kapsamında, yapılan tüm bu analizlerden elde edilen sonuçlar doğrultusunda bireysel tüketici rant1 $26.309 \mathrm{TL}$, toplam tüketici rantı 10.349.329.184 TL/yıl olarak bulunmuştur. Hesaplanan Toplam Tüketici Rantı değeri, Bergama Antik Kenti'nin bir yıllık kültürel miras turizm kullanım değerine karşlık gelmektedir.

\section{SONUÇ VE ÖNERILER}

Kültürel miras alanlarının, turizm amacıyla kullanılması yani turizm sektöründe bir ürün olarak sunulması ile bu alanların ekonomik değerinin belirlenmesi konusu gündeme gelmiştir. Günümüzde yerli ve yabancı turistlerin piyasa dışı ürünlerden biri olan kültürel miras alanlarını ziyaret etme isteği ile de turizm faaliyeti meydana gelmiştir. Bu çalışmada Türkiye'nin önde gelen kültürel miras alanlarından biri olan Bergama Antik Kenti'nin kültürel miras turizmi kapsamında kullanılması sonucu sahip olduğu ekonomik değeri tespit etmek amaçlanmıştır. Çalışmada Bergama Antik Kenti'nin BSMY ile ekonomik değerinin tespiti için, 2019 Ağustos ayında alanı ziyaret eden 400 kişiye yüz yüze anket uygulanmıştır. Bu çalışmanın anket uygulaması, İzmir Kâtip Çelebi Üniversitesi Sosyal Araştırmalar Etik Kurulu'nun 08.08.2019 tarihli ve 2019/06-04 sayılı kararı ile onaylanmıştır. Seyahat maliyetini ölçmek için çoklu doğrusal regresyon modeli oluşturulmuştur. Modelin bağımlı değişkeni yıllık ziyaret sayısının (talep) bağımsız değişkenler tarafından hangi öncelik ve ne derecede açılandığı analiz edilmiştir. Bağımsız değişkenler ise seyahat maliyeti, konaklama süresi, otopark masrafı, toplam ziyaret sayısı, ziyaretçi sayısı, yıllık kültür gezisi süresi ve ziyarete ayrılan süre olmak üzere toplam yedi bağımsız değişken kullanılmıştır. Çoklu doğrusal regresyon analizinde Bergama Antik Kenti için yıllık bireysel tüketici rantı ve toplam tüketici rantı hesaplanmıştır. Bergama Antik Kenti'ni ziyaret eden turistlerin bireysel tüketici rantı $26.309 \mathrm{TL}$, toplam tüketici rant1 ise 10.349.329.184 TL/yıl olarak hesaplanmıştır. Bireysel tüketici rantı, alanı ziyaret eden bir ziyaretçinin bu ziyaretten elde ettiği faydanın ekonomik değerini ifade etmektedir. Toplam tüketici rantı ise toplam ziyaretçilerin alandan elde 
ettiği faydanın ekonomik değerini belirtmektedir. Çalışmanın sonucunda elde edilen bulgular, dünya miras listesinde olan Bergama Antik Kenti'nin kültürel miras turizmi amaciyla kullanılmasının yerli ve yabancı turistlere sağladığ 1 faydayı temsil etmektedir. Bu sonuca göre bireylere kattığı değerler göz önüne alındığında kültürel miras alanlarının kültürel miras turizmine kazandırılmasının önemi ortaya çıkmaktadır.

Alanyazın incelendiğinde, BSMY ile yapılan yerli ve yabancı birçok çalışma bulunmaktadır. BSMY'nin kullanıldığı ekonomik değer belirleme çalışmalarında ele alınan konuların; akarsu raftingi (Bowker vd. 1996), yağmur ormanları (Menkhaus ve Lober 1996), milli parklar (Başar 2007; Yılmaz 2016; Alkan 2019; Özkök vd. 2019), tabiat pakları (Ortaçeşme vd. 2002; Dönmez 2012), kaplicalar (Belkayalı 2009; Apostolidis 2017), göller (Mangan vd. 2013) botanik bahçeleri (Demir 2013) ve plajlar (Zhang vd. 2015) olduğu tespit edilmiştir. Bunun yanında daha önce yap1lan çalışmalarda BSMY uygulamalarında çoklu doğrusal regresyon, yarı logaritmik regresyon, poission regresyon ve negatif binom regresyon gibi çeşitli modeller ve bu modellere ilişkin geliştirilen farklı tüketici rantı formülleri kullanılmıştır. Her regresyon modeline ait farklı tüketici rantı formüllerinden dolayı aynı çalışmanın verilerinin sonucunda bile farklı (yüksek veya düşük) tüketici rantlarının hesaplanmasına neden olmuştur. Çalışma sonucunda bulunan değerler, alanyazındaki çalışmalarda bulunan değerler ile karşılaştırıldığında, bu çalışmanın bireysel tüketici rantının diğer çalışmalara göre daha fazla bulunması; farklı model ve fonksiyon tipi kullanılması (doğrusal fonksiyon $T R=-q^{\wedge} 2 / 2 \beta$ ), çalışma alanının kültürel miras alanı olması, ülkelerin ekonomilerindeki farklılık gibi birçok faktörle açılanabilir. Bu çalışmanın sonuçları değerlendirildiğinde araştırmacıların BSMY uygulamalarında kullanılan regresyon modellerine uygun tüketici rantı formülleri kullanmaları önerilmektedir. Böylece kullanılan modele uygun farklı tüketici rantı formülleri sonucu elde edilen tüketici rantı değerleri aynı yöntem, model ve tüketici formülü kullanılan çalışmalar ile kıyaslanabilir.
Bu çalışmanın alanyazına katkısı Türkiye'de kültürel miras alanının ekonomik değerini belirleyen ve kültürel miras turizminin önemini vurgulayan bir çalışma olmasıdır. Bu çalışmada kullanılan yöntemler ileride yapılacak kültürel alanların ekonomik değerinin belirlenmesi çalışmalarına yol gösterecektir. Ayrıca benzer çalışmaların artması ile kültürel miras alanlarının tanınırlığgnın, değerinin ve turizm amaçlı kullanımının artması sağlanacaktır.

\section{KAYNAKÇA}

Adamowicz, W. L., Fletcher, J. J. ve Graham T. (1989). Functional Form and the Statistical Properties of Welfare Measures, American Journal of Agricultural Economics, 71 (2): 414-421.

Alberini, A. ve Longo, A. (2006). Combining the Travel Cost and Contingent Behavior Methods to Value Cultural Heritage Sites: Evidence from Armenia, Journal of Cultural Economics, 30 (4): 287-304.

Alkan, Y. (2019). Bireysel Seyahat Maliyet Yöntemi Kullanılarak Ekonomik Değer Tespiti: Troya Tarihi Milli Park1 Örneği, Bartın Orman Fakültesi Dergisi, 21 (3): 633-643.

Alora, J. ve Nandagiri, L. (2015). Evaluation of Economic Value of Pilikula Lake Using Travel Cost and Contingent Valuation Methods, Aquatic Procedia, 4: 1315- 1321.

Apostolidis, G. (2017). Applying a Travel Cost Method to Evaluate the Thermal Tourism in Greece: Case Study of Loutraki Arideas Springs, Proceedings of the 8th International Conference on Information and Communication Technologies in Agriculture, Food and Environment (HAICTA) (ss. 482-488). 21-24 Eylül 2017. Yunanistan: Hanya.

Baker, R. ve Ruting, B. (2014). Environmental Policy Analysis: A Guide to Non-Market Valuation, Productivity Commission Staff Working Paper. Canberra: Australian Government Productivity Commission.

Bann, C. (1998). The Economic Valuation of Tropical Forest Land Use Options: A Manual for Researchers. Economy and Environment Program for Southeast Asia. Singapore: Research Report Series.

Başar, H. (2007). Dilek Yarımadası-Büyük Menderes Deltası Milli Parkının Rekreasyon Amacıyla Kullanımının Ekonomik Değerinin Saptanması: Bir Seyahat Maliyeti Yöntemi Uygulaması (Basılmamış Yüksek Lisans Tezi). İzmir: Ege Üniversitesi Tarım Ekonomisi Ana Bilim Dali.

Belkayalı, N. (2009). Yalova Termal Kaplıcalarının Rekreasyonel ve Turizm Amaçlı Kullanımının Ekonomik Değerinin Belirlenmesi (Basılmamış Doktora Tezi). Ankara: Ankara Üniversitesi Peyzaj Mimarlığı Ana Bilim Dalı.

Bowker, J. M., English, D. B. K. ve Donovan J. A. (1996). Toward a Value for Guided Rafting on Southern Rivers, Journal of Agricultural and Applied Economics, 28 (2): 423432. 
Can, A. (2018). SPSS ile Bilimsel Araștırma Sürecinde Nicel Veri Analizi. Ankara: Pegem Akademi.

Clawson, M. ve Knetsch, J. (1966). Economics of Outdoor Recreation. Baltimore: John Hopkins Üniversitesi.

Czajkowski, M., Giergiczny, M., Kronenberg, J. ve Englin, J. (2019). The Individual Travel Cost Method with Consumer-Specific Values of Travel Time Savings, Environmental and Resource Economics, 74 (3): 961-984.

Das, S. (2013). Travel Cost Method for Environmental Valuation. Madras School of Economics Dissemination Paper 23. Hindistan: Madras.

Demir, A. (2013). Determination of the Recreational Value of Botanic Gardens, Kev, London, Hacettepe Journal of Biology and Chemistry, 41 (2): 87-102.

Demircioğlu, H. (2014). Karatepe-Aslantaş Milli Parkında Rekreatif Kullanımların Ekonomik Analizi ve Yönetsel Araştırmalar (Basılmamış Yüksek Lisans Tezi). Kahramanmaraş: Kahramanmaraş Sütçü İmam Üniversitesi Orman Mühendisliği Ana Bilim Dalı.

Dönmez, R. (2013). Trabzon İli Uzungöl Doğa Parkı'ndan Rekreasyonel ve Turizm Amaçlı Yararlanmanın Ekonomik Değerinin Belirlenmesi: Seyahat Maliyeti Yöntemi Uygulaması (Basılmamış Yüksek Lisans Tezi). Erzurum: Atatürk Üniversitesi Tarım Ekonomisi Ana Bilim Dalı.

Fleming, C.M. ve Cook, A. (2008). The Recreational Value of Lake McKenzie, Fraser Island: An Application of the Travel Cost Method, Tourism Management, 29 (6): 11971205.

Gülhan, D. (2016). Sürdürülebilir Kent ve Kentsel Kimlik Örnekler: Birgi ve Bergama (Basılmamış Doktora Tezi). Ankara: Ankara Üniversitesi Sosyal Çevre Ana Bilim Dalı.

Hotelling, H. (1949). The Economics of Public Recreation; An Economic Study of the Monetary Evaluation of Recreation in the National Park. Washington D.C.: Land and Recreational Planning Division, National Park Service.

Kalaycı, Ş. (2018). SPSS Uygulamalı Çok Değişkenli İstatistik Teknikleri. Ankara: Dinamik Akademi.

Mangan, T., Brouwer, R., Lohano, H. D. ve Nangraj, G. M. (2013). Estimating the Recreational Value of Pakistan's Largest Freshwater Lake to Support Sustainable Tourism Management Using a Travel Cost Model, Journal of Sustainable Tourism, 21(3): 473-486.
Mathis, M. L., Fawcet, A.A. ve Konda, L.S. (2004). Valuing Nature: A Survey of the Non-Market Valuation Literature, Discussion paper (ss. 93-98), VNT03-01, Houston Advanced Research Center: ABD

Menkhaus, S. ve Lober, D. J. (1996). International Ecotourism and the Valuation of Tropical Rainforests in Costa Rica, Journal of Environmental Management, 47 (1) :1-10.

Ortaçeşme, V., Özkan, B. ve Karagüzel, O. (1999). Rekreasyon Alanlarının Ekonomik Değerinin Saptanmasında Seyahat Maliyeti Yönteminin Kullanımı, Akdeniz Üniversitesi Ziraat Fakültesi Dergisi, 12 (1): 107-120.

Ortaçeşme, V., Özkan, B. ve Karagüzel, O. (2002). An Estimation of The Recreational Use Value of Kursunlu Waterfall Nature Park by the Individual Travel Cost Method, Turkish Journal of Agriculture and Forestry, 26 (1): 57-62.

Ortega, S.T., Alvarez, R.P., Simal, P.D., Luis-Ruiz, J. M. ve Garcia, F.P. (2018). Economic Valuation of Cultural Heritage: Application of Travel Cost Method to the National Museum and Research Center of Altamira, Sustainability, 10 (7): 1-13.

Özkök, F., Mercan, Ş. O., Yıldırım, H.M., Korkmaz, H., Sünnetçioğlu, S. ve Ayhan, Ç. (2019). Kaz Dağları'nın Turizmdeki Ekonomik Değerinin Seyahat Maliyet Yöntemi ile Belirlenmesi, Elektronik Sosyal Bilimler Dergisi, 18 (69): 412-424.

Pak, M. (2003). Orman Kaynağından Rekreasyonel Amaçlı Yararlanmanın Ekonomik Değerinin Tahmin Edilmesi ve Bu Değer Üzerinde Etkili Olan Değişkenler Üzerine Bir Araştırma (Basılmamıs Doktora Tezi). Trabzon: Karadeniz Teknik Üniversitesi Orman Mühendisliği Ana Bilim Dalı.

Willis, K.G. ve Garrod, G.D. (1991). An Individual Travel Cost Method of Evaluating Forest Recreation, Journal of Agricultural Economics, 42 (1): 33-42.

Yılmaz, F. (2016). Beydağları Sahil Milli Parkı'nın Rekreasyonel Değeri'nin Belirlenmesi: Seyahat Maliyeti ve Koşullu Değerleme Yöntemi Örneği (Basılmamış Yüksek Lisans Tezi). Antalya: Akdeniz Üniversitesi İktisat Ana Bilim Dalı.

Zhang, F., Wang, X.H., Nunes, P.A.L.D. ve Ma, C. (2015). The Recreational Value of Gold Coast Beaches, Australia: An Application of the Travel Cost Method, Ecosystem Services, 7 (1): 106-114. 


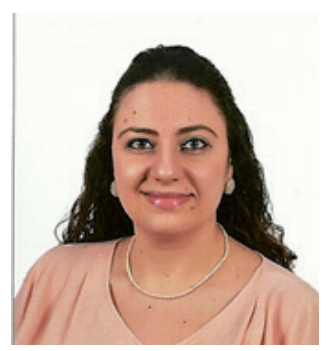

\section{Gülsüm SADIK}

Yaşar Üniversitesi, Turizm İşletmeciliği Bölümü’nden mezun oldu (2013). İzmir Kâtip Çelebi Üniversitesi Sosyal Bilimler Enstitüsü Turizm İşletmeciliğ Ana Bilim Dalı'nda yüksek lisans yapmaktadır.

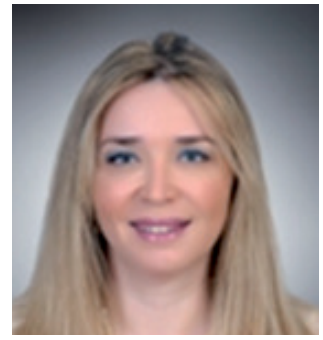

Seda SÜER

Dokuz Eylül Üniversitesi, Çalışma Ekonomisi ve Endüstri İlişkileri Bölümü'nden mezun oldu (1999). Master derecesini Dokuz Eylül Üniversitesi, İngilizce İşletme Yönetimi Ana Bilim Dalı'ndan (2005), yüksek lisans derecesini Dokuz Eylül Üniversitesi, Muhasebe ve Finansman Ana Bilim Dalı́ndan aldı (2009). Doktora derecesini Dokuz Eylül Üniversitesi İşletme Anabilim Dalı́ndan aldı (2014). İzmir Kâtip Çelebi Üniversitesi, Turizm Fakültesi'nde halen Doktor Öğretim Üyesi (2017) olarak görev yapmaktadır. 